\title{
Sistem Pendeteksi Penggunaan Masker dengan Metode Convolutional Neural Network pada Sistem Portal Otomatis
}

\author{
Alwifran Fahlifi ${ }^{1}$, Heriansyah $^{1}$, Afit Miranto $^{3}$ \\ ${ }^{1}$ Institut Teknologi Sumatera \\ ${ }^{2}$ Institut Teknologi Bandung \\ ${ }^{3}$ Universitas Lampung \\ *alwifran.13117068@student.itera.ac.id
}

\begin{abstract}
The very fast spreading process of COVID-19 has made this virus a pandemic in various countries. To reduce the spread of the COVID-19 virus, it is mandatory for everyone to follow health protocol rules such as social distancing and wearing masks. The health protocol examination is carried out by special personnel before entering the mandatory area to use a mask, which of course this examination will require more energy and cannot be done every time. In this study, a tool was made that could detect health protocols which would later reduce the workload of special workers. This tool can detect the use of masks on a person, which is made using the MobileNetV2 architecture and the Convolutional Neural Network (CNN) method that classifies people as not wearing masks and wearing masks. This tool uses the Raspberry Pi as a mini computer which is the main brain by adding a camera sensor to detect someone using a mask in real-time, RGB LEDs as a marker of whether the mask is detected or not, and the LCD as a display when the system is running. The effective distance that can detect the use of masks is as far as 30-200 cm.
\end{abstract}

Keywords: CNN, COVID-19, mask, MobileNetV2, Raspberry Pi, camera sensor.

\section{INTISARI}

Proses penyebaran sangat cepat pada COVID-19 membuat virus ini menjadi pandemi di berbagai negara. Untuk mengurangi penyebaran pada virus COVID-19, diwajibkan untuk setiap orang mengikuti aturan protokol kesehatan seperti, sosial distancing dan menggunakan masker. Pemeriksaan protokol kesehatan dilakukan oleh tenaga khusus sebelum memasuki area wajib menggunakan masker, dimana tentunya pemeriksaan ini akan membutuhkan tenaga yang lebih banyak dan tidak dapat dilakukan setiap waktu. Pada penelitian ini, dibuatlah sebuat alat yang dapat mendeteksi protokol kesehatan yang nantinya dapat mengurangi beban kerja dari tenaga khusus. Alat ini dapat mendeteksi pemakaian masker pada seseorang, yang dibuat menggunakan arsitektur MobileNetV2 dan metode Convolutional Neural Network (CNN) yang mengklasifikasikan orang tidak menggunakan masker dan menggunakan masker. Alat ini menggunakan Raspberry Pi sebagai mini computer yang menjadi otak utamanya dengan menambahkan sensor kamera untuk mendeteksi seseorang menggunakan masker secara real-time, LED RGB sebagai penanda apakah masker terdeteksi atau tidak, dan LCD sebagai display ketika sistem dijalankan. Jarak efektif yang bisa untuk mendeteksi penggunaan masker adalah sejauh $30-200 \mathrm{~cm}$.

Kata kunci: CNN, COVID-19, masker, MobileNetV2, Raspberry Pi, sensor kamera.

\section{PENDAHULUAN}

Pada akhir tahun 2019, terdapat sebuah virus yang menyebabkan kematian dengan tingkat penyebaran yang sangat tinggi yaitu Severe Acute
Respiratory Syndrome Virus Corona 2 (SARSCoV-2). Berdasarkan data dari Badan Nasional Penanggulangan Bencana (BNPB), penyebaran virus COVID-19 di Indonesia sudah mencapai

Jurnal ELECTRON, Vol. 2, No.2, November 2021: 89-96 
16.006 kasus positif dan 1.043 dinyatakan meninggal dunia.

World Health Organization (WHO) menganjurkan menggunakan masker ketika beraktivitas di luar untuk mengurangi dampak penyebaran dan penularan dari COVID-19, akan tetapi ketidakpatuhan sebagian masyarakat Indonesia terhadap protokol kesehatan menjadi keresahan bagi masyarakat lainnya. Oleh karena itu, perlu adanya sebuah sistem pendeteksi penggunaan masker untuk mencegah orang yang tidak memakai masker masuk ke wilayah wajib bermasker.

Seiring dengan perkembangan teknologi saat ini, dibuatlah alat untuk mendeteksi masker, dimana alat ini merupakan bagian dari Sistem Portal Otomatis Deteksi Wajah, Suhu Tubuh dan Masker (SPOTKASTER). Alat ini diperuntukkan untuk pegawai, dimana nantinya portal akan terbuka dan tertutup secara otomatis ketika mendeteksi apakah pegawai tersebut menggunakan masker, memiliki suhu tubuh di bawah $37^{\circ} \mathrm{C}$ dan juga akan mendeteksi wajah sebagai presensi pegawai. Sistem ini dibuat menggunakan Raspberry Pi sebagai microcontroller yang menjadi otak utamanya dengan menambahkan sensor kamera untuk mendeteksi seseorang menggunakan masker secara real-time dan juga sistem ini menggunakan arsitektur MobileNetV2 dengan metode Convolutional Neural Network (CNN) yang mengklasifikasikan orang menggunakan masker dan tidak menggunakan masker.

\section{LANDASAN TEORI}

\section{A. COVID-19}

Pertama kali penyebaran virus Covid-19 terjadi di kota Wuhan, China pada akhir Desember 2019. Karena proses penyebarannya yang sangat cepat, membuat virus ini menyebar hampir ke semua negara, termasuk Indonesia. Virus ini menyebar melalui tetesan kecil yang dihasilkan selama berbicar, bersin, dan batuk.

Adapun gejala awal yang muncul ketika terinfeksi virus COVID-19, yaitu seperti gejala flu, sakit tenggorokan, batuk kering, demam, dan sakit kepala. Sedangkan gejala berat yang dialami oleh penderita adalah batuk berdahak sampai berdarah, nyeri dada, sesak napas, dan demam tinggi. Semua gejala yang disebutkan akan didapatkan ketika tubuh bereaksi melawan virus tersebut kurang lebih dalam waktu 2 hari sampai 2 minggu.

\section{B. SPOTKASTER}

Sistem Portal Otomatis Deteksi Wajah, Suhu Tubuh dan Masker (SPOTKASTER) merupakan sebuah alat yang menerapkan sistem kendali otomatis pada portal berbasis penggunaan masker, pengecekan suhu tubuh, dan pengecekan wajah untuk melakukan presensi. Alat ini digunakan khusus untuk pegawai karena nantinya ketika melakukan presensi, datanya akan tersimpan ke dalam database sebagai pegawai. Sedangkan untuk orang yang bukan pegawai, hanya akan diperiksa dan di cek protokol kesehatannya, yaitu pengecekan suhu tubuh dan penggunaan masker. Alat ini dibuat untuk memutus rantai penyebaran virus COVID-19, meningkatkan efisiensi waktu dalam antrian, dan memudahkan petugas dalam melakukan pengecekan protokol kesehatan.

Cara kerja dari SPOTKASTER adalah user mendekatkan wajahnya ke depan LCD untuk dilakukan pengecekan penggunaan masker, suhu tubuh dan wajah sebagai presensi. Apabila semuanya sudah sesuai dengan sistem, maka portal akan terbuka secara otomatis dengan notifikasi dari buzzer yang berbunyi selama satu detik dan lampu LED yang berwarna hijau. Akan tetapi ketika sistem mendeteksi user tidak memenuhi salah satu dari protokol kesehatan yang ada, maka lampu LED akan berwarna merah dan buzzer tidak akan berbunyi dan, sehingga user tidak diberikan akses untuk masuk.

\section{Convolutional Neural Network}

CNN memiliki neuron yang terdiri dari bias, weight, dan activation function. Cara kerja dari CNN adalah menggunakan proses konvolusi dengan menggerakan kernel konvolusi (filter) berukuran tertentu ke citra atau gambar, maka komputer akan menerima informasi dari hasil perkalian filter yang digunakan dengan bagian gambar. CNN memiliki 3 layer yang digunakan, yaitu:

1. Convolution Layer

Konvolusi adalah operasi matematika yang menggeser satu fungsi ke fungsi lainnya dan 
mengukur integral dari perkalian titik - titiknya. Tujuan dari konvolusi ini adalah mengekstraksi fitur dari citra input.

\section{Pooling Layer}

Pooling layer merupakan filter yang bergeser pada seluruh area feature map. Tujuan dari pooling layer ini adalah untuk mempercepat komputasi dengan mengurangi dimensi dari feature map.

3. Fully Connected Layer

Fully connected layer diimplementasikan di akhir jaringan karena kalau diimplementasikan dari awal nantinya data akan kehilangan informasi spasialnya dan tidak reversibel. Tujuan dari fully connected layer adalah untuk mentrasformasi dimensi data agar bisa diklasifikasikan secara linear

\section{Komponen Penelitian}

Sistem pendeteksi masker ini memiliki beberapa komponen hardware dan software yaitu sensor kamera, Raspberry Pi, LCD, LED, Python, OpenCV, TensorFlow.

1. Raspberry Pi

Raspberry pi adalah mini computer yang fiturnya sama dengan komputer pada umumnya, seperti memprogram, office, dan juga terdapat HDMI, port USB, dan LAN. Untuk mendeteksi masker menggunakan Raspberry Pi 4 model B

\section{Sensor kamera}

Sensor kamera berfungsi untuk mendeteksi pemakaian masker pada seseorang, dimana sensor kamera dapat mengambil video dan foto dengan definisi tinggi. Sensor kamera yang digunakan adalah OmniVision OV5647.

\section{LED}

Light Emitting Diode (LED) ketika diberikan tegangan maju akan memancarkan cahaya monokromatik. Pada alat ini, LED yang dipakai adalah LED RGB yang berfungsi sebagai pemberi informasi ketika user menggunakan masker dengan lampu berwarna hijau dan lampu berwarna merah ketika tidak menggunakan masker.

\section{LCD}

Liquid Crystal Display (LCD) merupakan sebuah display yang menampilkan output dari sistem pada sebuah layar. LCD yang digunakan adalah LCD 7inch dan berfungsi sebagai display ketika sistem sudah mulai dijalankan.
5. Python

Python merupakan bahasa pemrograman tingkat tinggi, sehingga banyak digunakan untuk membuat program GUI, web, game, dsb. Python merupakan bahasa pemograman resmi dari Raspberry Pi.

\section{OpenCV}

OpenSource Computer Vision Library (OpenCV) adalah library software yang digunakan untuk mengolah citra dinamis secara real-time. OpenCV juga merupakan sebuah aplikasi komersial berbasis penginderaan citra. Adapun beberapa pengembangan dan project - project dari OpenCV yaitu face recognition, face detection, object tracking, dll.

\section{TensorFlow}

Tensorflow ini adalah sebuah tool yang dapat melakukan machine learning (neural network, dan sebagainya) dan komputasi numerik.

\section{METODE PENELITIAN}

Dalam penelitian rancangan alat pendeteksi masker pada SPOTKASTER berbasis kesehatan ini, akan dibuat menggunakan sensor, komponen pendukung dan software.

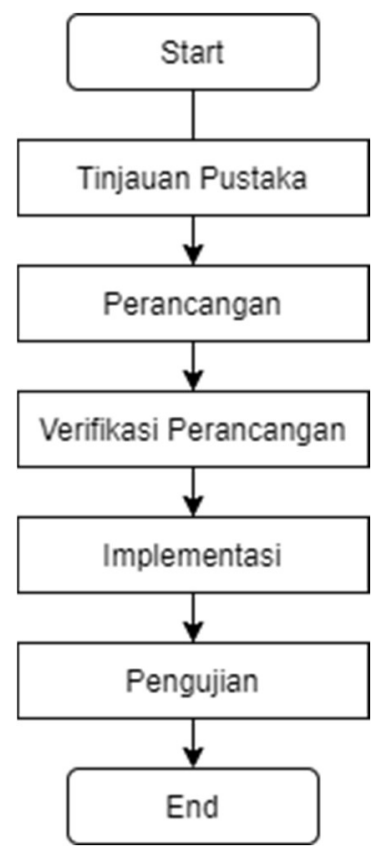

Gambar 1. Metodologi penelitian 
Pada tahap awal penelitian, diperlukan peninjauan terhadap penelitian - penelitian terdahulu mengenai pembuatan alat pendeteksi masker, cara kerja, serta kelebihan dan kekurangannya. Dengan membandingkan beberapa pengalaman penelitian terdahulu, maka diharapkan penelitian ini memiliki nilai lebih. Pada tahap ini juga, penulis perlu melakukan peninjauan terhadap apa aja komponen yang akan dipakai pada tahap perancangan dan meninjau metode pengujian yang tepat untuk digunakan.

Pada tahap perancangan, penulis akan memilih komponen apa saja yang digunakan untuk mendukung sistem bekerja menjadi lebih baik. Pada tahap ini, penulis akan membuat rancangan untuk desain alat SPOTKASTER.

Pada tahap verifikasi perancangan, semua komponen yang dibutuhkan akan diverifikasi dengan menguji masing - masing komponen. Tujuan dilakukan pengujian adalah untuk memastikan bahwa komponen dapat bekerja dengan baik dan sesuai dengan yang kita mau.

Pada tahap implementasi, penulis melakukan proses assembly menggunakan semua komponen yang ada pada tahap perancangan agar sesuai dengan desain alat SPOTKASTER. Setelah semua selesai dirakit, SPOTKASTER siap untuk dilakukan pengujian.

Pada tahap akhir penelitian, penulis melakukan pengujian secara menyeluruh pada alat SPOTKASTER. Dimana setelah pengujian akan didapatkan hasil data sesuai dengan kondisi yang diinginkan ketika pertama kali membuat alat ini.

\section{A. Diagram Blok}

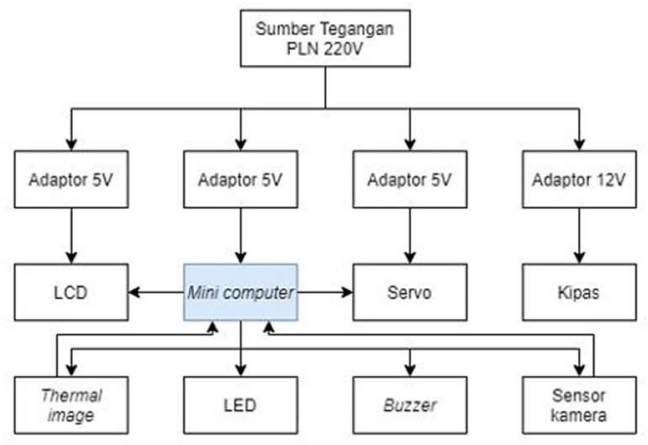

Gambar 2. Diagram blok sistem
Dapat dilihat bahwa sumber tegangan utama SPOTKASTER berasal dari PLN dengan 220V, dimana sumber tegangan itu akan tersambung ke 4 buah adaptor, yaitu 3 buah adaptor $5 \mathrm{~V}$ dan 1 buah adaptor $12 \mathrm{~V}$. Masing - masing adaptor ini terhubung ke komponen yang berbeda - beda, yaitu LCD, mini computer Raspberry Pi 4 model B, servo, dan kipas. Untuk menggerakkan kipas supaya bekerja dengan optimal digunakanlah adaptor $12 \mathrm{~V}$, supaya nantinya ketika sistem dijalankan dapat mengurangi panas dari LCD dan mini computer. Untuk komponen lainnya, seperti sensor kamera, sensor thermal image, LED, dan buzzer akan terhubung ke mini computer dengan pin - pin yang ada pada mini computer. Hasil inputan yang didapatkan dari sensor akan diproses dan diolah datanya oleh mini computer, dimana nanti hasilnya akan ditampilkan pada LCD dan servo untuk menggerakkan portal ketika syarat sistem sudah terpenuhi atau belum terpenuhi.

\section{B. Flowchart Sistem}

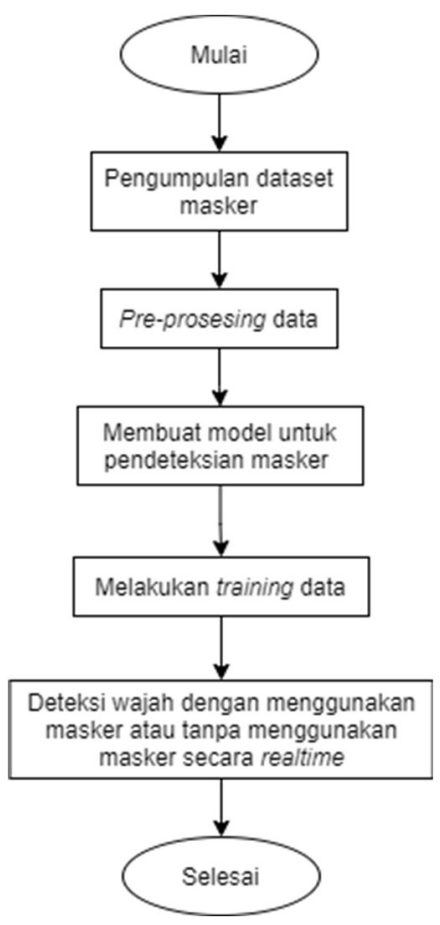

Gambar 3. Flowchart sistem 
Sistem pendeteksi masker ini menggunakan metode Convolutional Neural Network (CNN). Untuk bisa mendeteksi pemakaian masker pada seseorang dibutuhkan dataset, dimana dataset ini berupa wajah orang memakai masker dan wajah orang tidak menggunakan masker. Dataset yang digunakan dibuat oleh Prajna Bhandary dengan total gambar sebanyak 1376 foto, dengan 690 foto yang menggunakan masker dan 686 foto yang tidak menggunakan masker. Pada tahap pre-processing data terdiri dari pengolahan dan pengondisian gambar seperti, ukuran, pelabelan antara gambar dengan objek, dan pemfilteran. Pada tahap membuat model untuk mendeteksi masker, menggunakan arsitektur MobileNetV2. Arsitektur ini memiliki kelebihan untuk mengatasi kebutuhan resource komputasi yang tinggi dan nilai akurasi yang tergolong baik. Selanjutnya melakukan training data dari model yang telah dibuat. Training dataset yang dilakukan dibagi menjadi 20 untuk validasi pengujian dan $80 \%$ untuk training. Hasil dari training berupa nilai akurasi dan loss. Selanjutnya melakukan pendeteksian wajah dengan menggunakan masker dan tanpa menggunakan masker secara real-time.

\section{HASIL PENELITIAN DAN PEMBAHASAN}

\section{A. Pengujian untuk Mendeteksi Penggunaan Menggunakan Masker}

Dengan membuat model untuk masker dan melakukan training setelah itu, didapatkan hasil seperti pada gambar (d) yang berhasil mendeteksi masker secara real-time dan akan muncul tulisan pada LCD "Terima kasih, Masker terdeteksi" dan lampu LED berwarna hijau. Sedangkan gambar (e) berhasil mendeteksi seseorang tidak menggunakan masker secara real-time dengan muncul tulisan pada LCD "Perhatian !!! Silahkan gunakan masker" dan lampu LED berwarna merah.

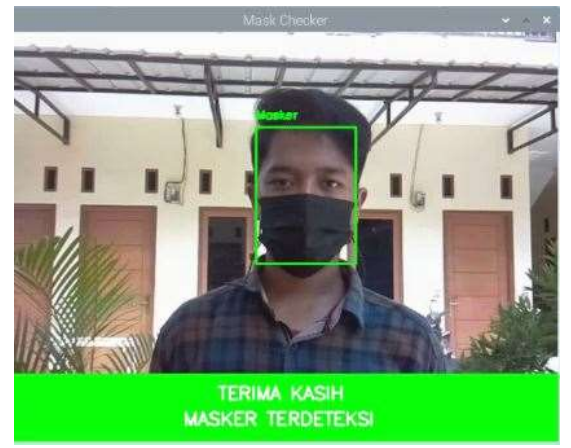

Gambar 4. Implementasi seseorang menggunakan masker

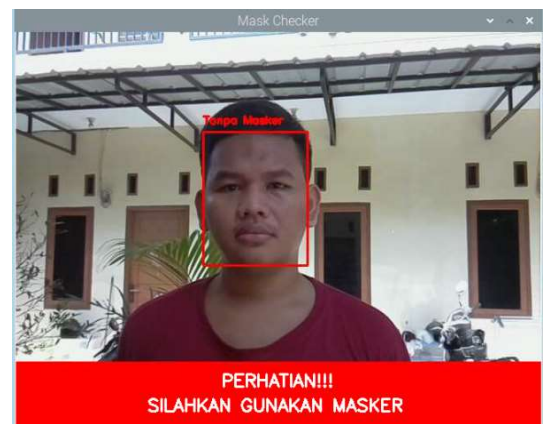

Gambar 5. Implementasi user tidak menggunakan masker

\section{B. Pengujian Berdasarkan Banyak Orang}

Pengujian yang dilakukan ini bertujuan untuk mengetahui berapa banyak orang yang dapat dideteksi dan berapa persen tingkat keberhasilannya. Ketika 5 orang berdiri di depan alat untuk dideteksi maskernya, terlihat bahwa frame pada sensor kamera sudah hampir terisi penuh, kecuali mereka berdiri agak jauh dari alat dan kemungkinan jumlah orang yang terdeteksi bisa melebihi dari 5 orang. Apabila dari 5 orang yang akan dideteksi maskernya hanya menggunakan masker sebanyak 4 orang, maka tampilan yang muncul pada LCD adalah "Terima kasih, Masker terdeteksi" dan LED berwarna hijau. Apabila dari 3 orang yang akan dideteksi maskernya hanya menggunakan masker sebanyak 1 orang, maka tampilan yang muncul pada LCD adalah "Perhatian!!! Silahkan gunakan masker" dan LED berwarna merah. Jadi sistem akan bekerja berdasarkan banyaknya atau mayoritas orang yang tidak menggunakan masker atau menggunakan masker. 
Jurnal ELECTRON, Vol. 2, No.2, November 2021, Hal. 89-96

e-ISSN 2622-6588 / p-ISSN 2830-523X

DOI: $10.33019 /$ electron.v2i2.6

Tabel 1. Pengujian berdasarkan banyak orang

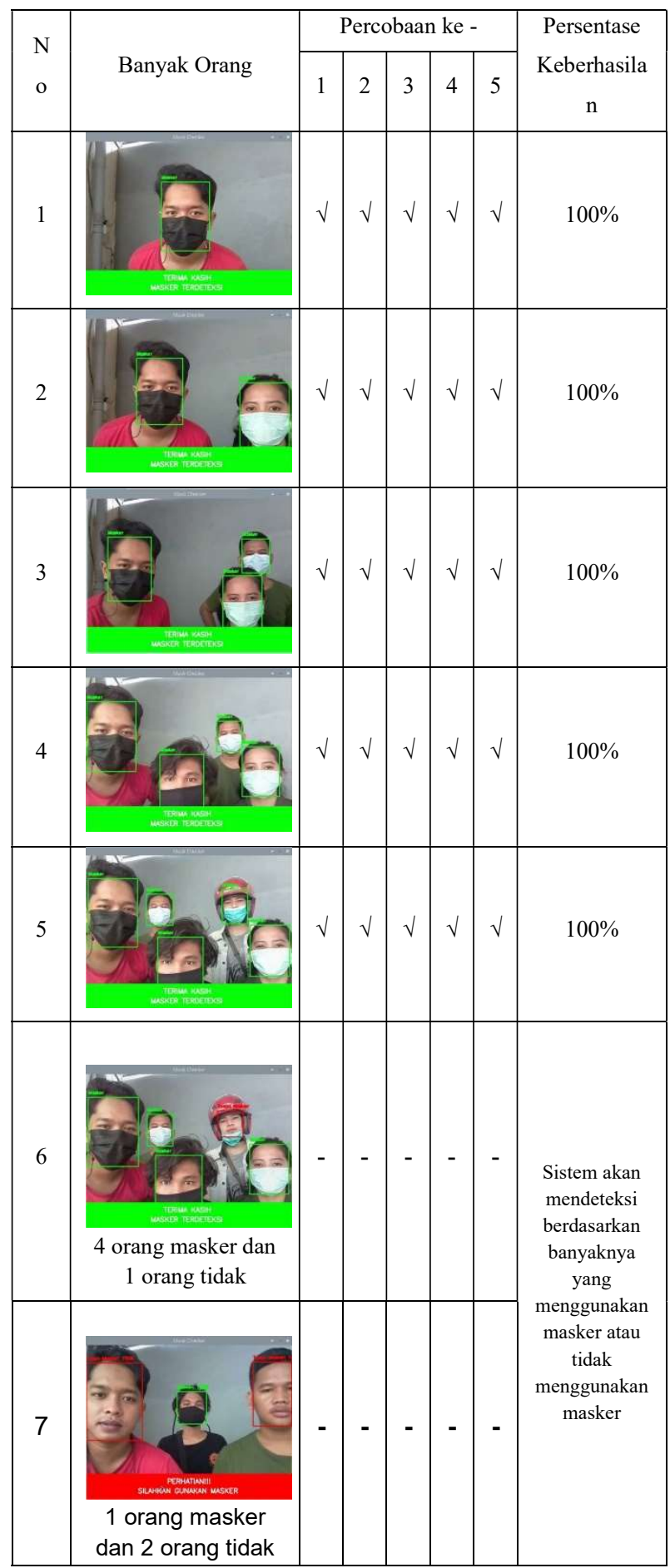

C. Pengujian Berdasarkan Benda selain Masker

Pengujian ini dilakukan untuk mengetahui apakah benda selain masker dapat dideteksi oleh sistem atau tidak. Dari data yang didapatkan, ketika hidung dan mulut tertutup menggunakan apa saja, sistem akan menganggap bahwa user sudah menggunakan masker. Itu terjadi karena ketika mengklasifikasikan masker wajah hanya terdiri dari 2 kelas yaitu kelas untuk tidak menggunakan masker dan kelas untuk menggunakan masker, sehingga dibutuhkan satu kelas untuk benda yang meragukan ketika berada di wajah atau outline dari maskernya yang tidak jelas.

Tabel 2. Pengujian berdasarkan selain masker

\begin{tabular}{|c|c|c|c|c|c|c|c|}
\hline \multirow{2}{*}{ No } & \multirow{2}{*}{ Benda selain masker } & \multicolumn{5}{|c|}{ Percobaan ke - } & \multirow{2}{*}{$\begin{array}{l}\text { Persentase } \\
\text { Keberhasilan }\end{array}$} \\
\hline & & 1 & 2 & 3 & 4 & 5 & \\
\hline 1 & & $\sqrt{ }$ & $\sqrt{ }$ & $\sqrt{ }$ & $x$ & $\sqrt{ }$ & $80 \%$ \\
\hline 2 & & $\sqrt{ }$ & $\sqrt{ }$ & $\sqrt{ }$ & $\sqrt{ }$ & $\sqrt{ }$ & $100 \%$ \\
\hline 3 & & $x$ & $x$ & $x$ & $x$ & $x$ & $0 \%$ \\
\hline & Tar & & & & & & \\
\hline
\end{tabular}

\section{Pengujian Berdasarkan Jarak}

Pengujian yang dilakukan ini bertujuan untuk mendapatkan berapa jarak efektif dari alat ini untuk bisa mendeteksi masker pada user. Pada pengujian ini dilakukan percobaan sebanyak 5 kali. Pada pengujian ini jarak paling jauh yang dapat dideteksi penggunaan maskernya adalah sejauh $240 \mathrm{~cm}$ dengan persentase keberhasilan sebesar 40\% sedangkan jarak paling dekat yang dapat dideteksi penggunaan maskernya adalah sejauh $20 \mathrm{~cm}$ dengan persentase keberhasilan sebesar $60 \%$. Dari data yang didapatkan, jarak efektif yang dapat membuat sistem bekerja lebih optimal adalah sejauh $30-200$ $\mathrm{cm}$ dengan persentase keberhasilan sebesar $100 \%$. Ketika berada pada jarak $20 \mathrm{~cm}$, sistem mendeteksi selain user di sebelah kanan atau kiri yang 
Jurnal ELECTRON, Vol. 2, No.2, November 2021, Hal. 89-96

e-ISSN 2622-6588 / p-ISSN 2830-523X

DOI: $10.33019 /$ electron.v2i2.6

memungkinkan terjadinya error karena terlalu dekatnya wajah ke sensor kamera yang membuat frame pada sensor kamera penuh dan sulit untuk dideteksi.

Tabel 3. Pengujian berdasarkan jarak

\begin{tabular}{|c|c|c|c|c|c|c|c|}
\hline \multirow{2}{*}{ No } & \multirow{2}{*}{ Jarak } & \multicolumn{5}{|c|}{ Percobaan ke - } & \multirow{2}{*}{$\begin{array}{c}\text { Persentase } \\
\text { Keberhasila } \\
\text { n }\end{array}$} \\
\hline & & 1 & 2 & 3 & 4 & 5 & \\
\hline 1 & & $\sqrt{ }$ & $x$ & $\sqrt{ }$ & $x$ & $x$ & $40 \%$ \\
\hline 2 & & $\sqrt{ }$ & $\sqrt{ }$ & $\sqrt{ }$ & $\sqrt{ }$ & $\sqrt{ }$ & $100 \%$ \\
\hline 3 & & $\sqrt{ }$ & $\sqrt{ }$ & $\sqrt{ }$ & $\sqrt{ }$ & $\sqrt{ }$ & $100 \%$ \\
\hline 4 & & $\sqrt{ }$ & $\sqrt{ }$ & $\sqrt{ }$ & $\sqrt{ }$ & $\sqrt{ }$ & $100 \%$ \\
\hline 5 & & $\sqrt{ }$ & $x$ & $\sqrt{ }$ & $x$ & $\sqrt{ }$ & $60 \%$ \\
\hline & 20 & & & & & & \\
\hline
\end{tabular}

\section{E. Pengujian Deteksi Masker Berdasarkan Jenis Masker}

Pengujian ini dilakukan untuk mengetahui apakah alat ini bisa mendeteksi jenis - jenis masker biasa ditemui. Pada pengujian ini jenis masker yang digunakan adalah masker non-medis, masker scuba, masker bedah, masker KN95, dan masker dengan gambar hidung dan mulut. Dari data yang didapatkan, sistem berhasil mendeteksi semua jenis masker dan variasi warnanya kecuali masker dengan gambar hidung dan mulut. Pada masker dengan gambar hidung dan mulut didapatkan persentase keberhasilan sebesar $20 \%$, itu terjadi karena outline dari masker yang tidak jelas dan menyerupai seperti hidung dan mulut. Untuk mendeteksi penggunaan masker pada user, sistem akan mendeteksi apakah hidung dan mulut sudah tertutup dengan benar atau belum, sedangkan bentuk dari masker tersebut membuat sistem mendeteksi tidak menggunakan masker.

Tabel 4. Pengujian berdasarkan jenis masker

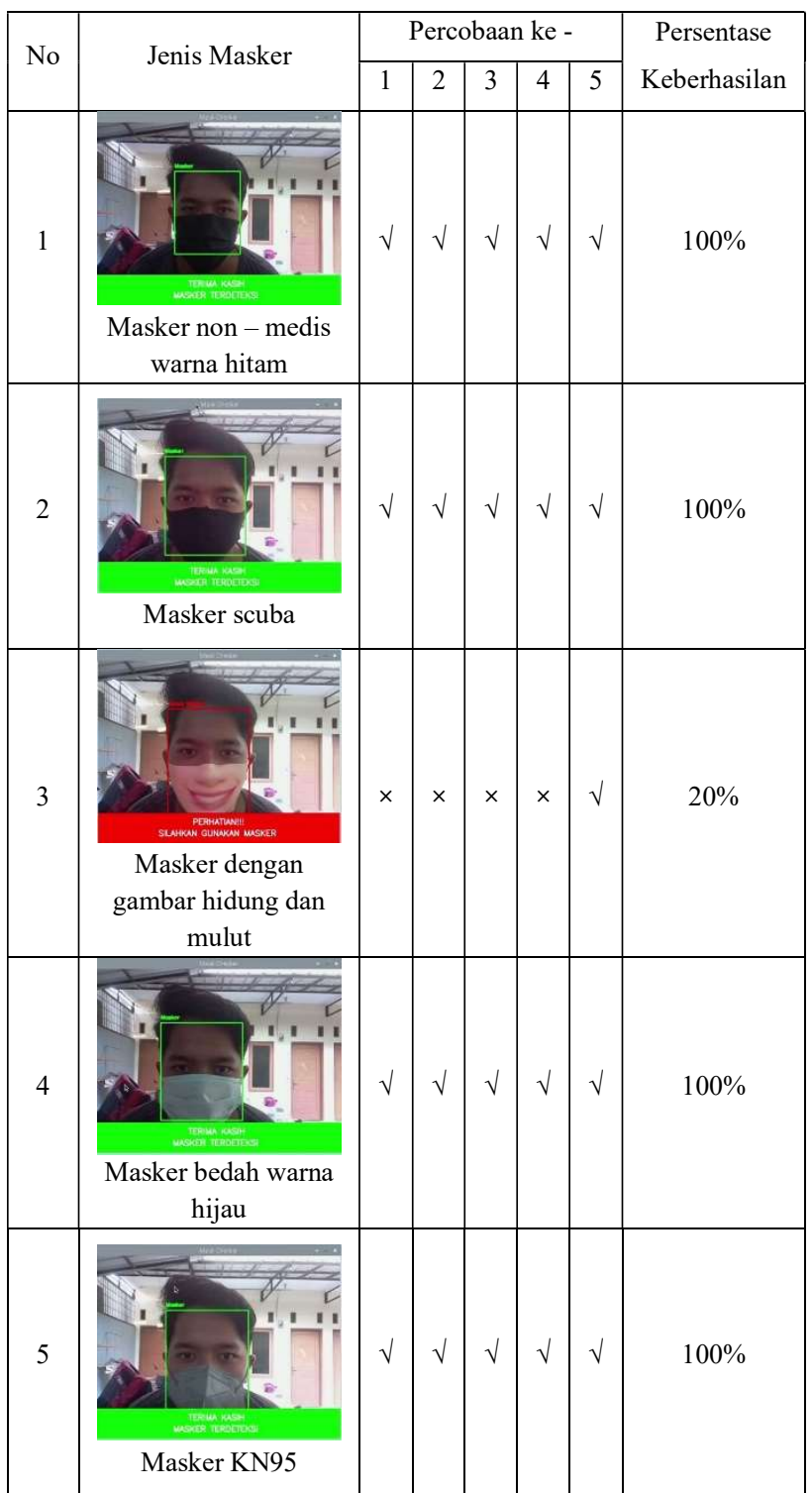




\section{F. Pengujian Penyimpanan Data Deteksi Masker pada Database}

Pengujian ini dilakukan untuk mengetahui apakah setelah mendeteksi masker pada user, datanya tersimpan di dalam database atau tidak. Ketika user menggunakan atau tidak menggunakan masker akan tersimpan di dalam database pada localhost. Ketika user sudah melakukan deteksi masker, deteksi suhu tubuh, dan terdeteksi sebagai pegawai, maka akan tersimpan di dalam database. Akan tetapi, ketika user tidak dikenali oleh sistem karena bukan pegawai, maka tidak akan tersimpan di dalam database. Untuk tampilan dari database ini terdiri dari nama, jabatan, keterangan suhu tubuh, waktu melakukan presensi (jam dan tanggal), keterangan penggunaan masker, dan keterangan berhasil atau tidaknya presensi.

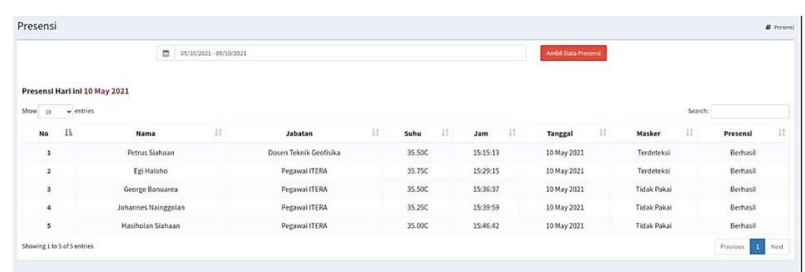

Gambar 6. Tampilan database deteksi masker pada localhost

\section{KESIMPULAN}

Setelah melakukan beberapa pengujian, didapatkan kesimpulan sebagai berikut:

1. Rancangan sistem untuk mendeteksi seseorang menggunakan masker yang dibuat berhasil dan bekerja dengan baik,

2. Sensor kamera yang digunakan untuk mendeteksi user menggunakan masker berhasil diimplementasikan,

3. Ketika masker terdeteksi akan muncul tulisan pada LCD "Terima kasih, Masker terdeteksi" dan lampu LED berwarna hijau dan ketika masker tidak terdeteksi akan muncul tulisan pada LCD "Perhatian!!! Silahkan gunakan masker" dan lampu LED berwarna merah,

4. Jarak efektif yang dapat membuat sistem bekerja lebih optimal adalah sejauh $30-200$ $\mathrm{cm}$.

\section{REFERENSI}

[1] Yuliana, "Corona Virus Disease (Covid-19)," Wellness and Healty Magazine, vol. 2, pp. 1-6, 2020.

[2] F. M. d. S. N. Putri Puspita, "Face Mask Detection Covid-19 Using Convolutional Neural Network (CNN)," Seminar Nasional Teknologi dan Rekayasa (SENTRA), vol. 2, pp. 27 - 32, 2020.

[3] L. C. d. P. J. N. Budirman Bunardi, "Pendeteksian Penggunaan Masker Wajah dengan Metode Convolutional Neural Network," Jurnal Ilmu Komputer dan Sistem Informasi, vol. 1, pp. 1-8, 2020.

[4] K. d. L. T. Rahim Arham, "Convolutional Neural Network untuk Klasifikasi Penggunaan Masker," Megister Teknik Informatika, Universitas AMIKOM Yogyakarta, vol. 1, p. 8, 2020.

[5] Yuliana, "Wellness and Healty Magazine," Corona Virus Diseases (COVID-19), vol. 2, pp. 1-6, February 2020.

[6] W. Y. d. S. R. Suartika Wayan, "Klasifikasi Citra Menggunakan Convolutional Neural Network (Cnn) pada Caltech 101," JURNAL TEKNIK ITS , vol. 5, pp. 1-5, 2016.

[7] D. Vincent, "Pengenalan Wajah Menggunakan Convolutional Neural Network," Tugas Akhir Institut Teknologi Sepuluh November, vol. 1, pp. 1134, 2018.

[8] S. Agus, "PERATURAN MENTERI PERDAGANGAN REPUBLIK INDONESIA," hukumonline.com, vol. 2, pp. 1-3, 2020.

[9] A. D. Nazwa, "Makalah Corona Virus Disease 2019," PENDIDIKAN JASMANI OLAHRAGA KESEHATAN, vol. 1, pp. 1-15, 2020.

[1 Faiz, "Pengenalan Teknologi dan Informasi,"

0] Raspberry Pi, 13 oktober 2017. [Online]. Available: http://17416255201065faizhariyanto.blogspot.com/ 2017/10/raspberry-pi.html. [Diakses 15 Maret 2021]. 